\title{
«Todos somos iguales». La Revolución de la Igualdad en Santa Cruz, Bolivia. 1876-1877
}

por

\author{
Andrey Schelchkov \\ Instituto de Historia Universal de la Academia de las Ciencias de Rusia \\ sch2000@mail.ru
}

La Revolución de Igualdad en Santa Cruz (1876-1877) o movimiento igualitario fue un conflicto entre el binomio formado por las capas plebeyas urbanas y las elites locales, defensoras de la fórmula del desarrollo que abogaba por una modernidad en equilibrio con los valores sociales de la sociedad patriarcal y tradicional, y otras elites locales, beneficiarias del auge del capitalismo de libre cambio. La actuación política de los igualitarios estuvo influenciada por las ideas del socialismo romántico en todas sus etapas y combinó formas legales con presión armada montonera y sublevación popular. El desajuste entre este proyecto de defensa de un autogestionado modo de vida local y las prioridades locales/estatales de modernización provocó una represión del mismo pocas veces vista en la sociedad cruceña en el siglo XIX.

Palabras clave: Revolución de la Igualdad; socialismo romántico; federalismo; guerra civil; Bolivia.

El objetivo de este estudio es analizar los acontecimientos acaecidos en Santa Cruz en la década de 1870 relativos al Movimiento Igualitario o la Revolución de la Igualdad -así llamada por haber sido protagonizada por el Club de Igualdad-y hacerlo desde una perspectiva analítica que aborda la formación del movimiento de resistencia popular y las formas relacionadas de acción colectiva de los «ciudadanos armados» ${ }^{1}$. Junto a libertades, racionalismo e

\footnotetext{
${ }^{1}$ La violencia política como forma universal del accionar social y político, véanse las siguientes obras. González-Calleja, 2002. Nieburg, 1969. Zimmermann, 2011. Tilly, 1977. Se toma la definición de Marta Irurozqui relativa a que «ciudadanía armada» o «pueblo en armas»
} 
individualismo, la modernidad asociada al cambio de régimen trajo el creciente control del Estado sobre esferas antes marginadas del interés político ${ }^{2}$. Este texto se interroga si a esa dinámica responden los sucesos políticos violentos sintetizados en la Revolución de Igualdad, y si la violencia desplegada por la misma fue una respuesta a la ejercida por el Estado. Aunque se asume al factor socio-económico como el trasfondo fundamental ${ }^{3}$ del conflicto socio-político cruceño, se opta por analizarlo desde la variedad de las prácticas políticas en las que se enmarcó por considerarse que las mismas, en su desarrollo, conformaron nueva propuestas y soluciones sociales que potenciaron las razones (locales, regionales y estatales) de la violencia. A partir de este enmarque se busca responder a tres cuestiones: primera, por qué el estallido revolucionario tuvo lugar en una región boliviana con aparente inexistencia de tensión, con gran homogeneidad social y sin tradición de rebelión popular; segunda, qué motivó una resistencia tan dura por parte de sus integrantes a la fuerza claramente superior de las autoridades centrales; y, tercera, qué hizo posible que ese movimiento adoptase tintes socialistas y federalistas. Con el objetivo de analizar y comprender las resistencias sociales y acciones colectivas del movimiento igualitario como parte consustancial del cambio social y político, se rechaza la visión unilateral que contrapone violencia y legalidad ${ }^{4}$. Los mecanismos de la violencia política en su forma de la movilización social se asumen como parte de la interacción del Estado, de la sociedad civil y de las grandes configuraciones sociales, que en la América Latina del XIX estuvieron sancionados constitucionalmente a través la noción de la «ciudadanía armada» como forma de llegar al consenso social ${ }^{5}$.

En la historiografía boliviana, la mayor parte de los estudios sobre la Revolución de la Igualdad se han reducido a ensayos hagiográficos sobre

alude al ejercicio constitucional -al tiempo deber y derecho- de la violencia por parte de la población para participar, gestionar y transformar el ámbito público (discusión historiográfica y bibliografía al respecto en Irurozqui, 2011c: 235-276).

2 El Estado en la modernidad aumenta sus funciones de supervisión y vigilancia en las esferas que en la sociedad preindustrial estaban bajo el control de los agentes sociales, tanto en lo laboral, político y cultural. Giddens, 1985: 147.

${ }^{3}$ La situación de las relaciones de la propiedad de tierra, de la diferenciación social en Santa Cruz del siglo XIX, todavía espera nuevas investigaciones ante la insuficiencia de las ya existentes (Roca, 2001. Soruco, 2008. Schelchkov, 2011).

${ }^{4}$ Véase esa propuesta en la introducción de Irurozqui y Galante, 2011. También en la de Galante, Irurozqui y Argeri, 2011.

${ }^{5}$ Estudios sobre los aspectos de violencia política en América Latina contribuyen esta visión amplificadora del asunto (Posada-Garbo, 1995. Sábato y Lettieri, 2003. Dunkerley, 2002. Fouler, 2006. Chust y Marchena, 2007. Irurozqui, 2009; 2012. Macías, 2011; 2014. Irurozqui y Galante, 2011. 
Andrés Ibáñez ${ }^{6}$. La tradición «nacional-popular», desde los trotskistas hasta la izquierda actual, se concentra en el carácter «antioligárquico», jacobino o socialista del movimiento igualitario y en la figura de Ibáñez como su «líder visionario» ${ }^{7}$. Romero Pittari realizó una pionera investigación del movimiento igualitario centrada en la crisis de la estructura de la sociedad tradicional, en cuyo seno aparecían fuertes contradicciones responsables de provocar una confrontación popular con la elite local beneficiada por un proceso de erupción capitalista ${ }^{8}$. Pese a lo interesante y relevante de sus propuestas y conclusiones, este trabajo carece de fuentes primarias y padece de simplificaciones sociológicas. La tesis sobre la homogeneidad racial y social de la sociedad tradicional en Santa Cruz ha sido un lugar común desde Gabriel Rene Moreno ${ }^{9}$ y al estar presente en la obra de Pittari hace que en ésta se prescinda de la complejidad de los procesos de mestizaje y de diferenciación social ocurridos en la segunda mitad del siglo, sobre todo en el seno de la elite, de los labradores agrícolas y del artesanado. Asimismo no es suficiente con afirmar la tesis común de la historiografía boliviana sobre la influencia de las ideas del socialismo romántico en el movimiento igualitario ${ }^{10}$, sino que se necesita presentar pruebas fidedignas al respecto. En respuesta a ambas críticas, este texto pretende matizar y ampliar lo referente a la interacción de las elites y las mayorías plebeyas dentro de la configuración local en su resistencia al cambio socio-político. Para ello incide en que la respuesta subversiva no solo combinó el tradicional contenido conservador de las formas de lucha de Antiguo Régimen con fórmulas ideológicas procedentes del socialismo romántico, sino que dicha interacción propició nuevas formulaciones y respuestas sociales e institucionales. Este enfoque no es contrario a tener presente la situación de la crisis en la sociedad cruceña provocada por los cambios en casi todas las esferas de la vida cotidiana, en especial en lo referente al acceso a la tierra, resultantes del comercio libre y del estancamiento económico entre el fin del auge de la quina y el inicio del boom de la goma o de la mayor presencia del Estado y su intromisión en los asuntos antes autorregulados por la sociedad local. Sin embargo, se dará relevancia analítica a los modos de accionar político, en concreto, a la combinación que hicieron los «igualitarios» de, por un lado, el movimiento cívico de los clubes y el debate en la prensa, y, de otro,

${ }^{6}$ Kramer, 1898. Sanabria Fernández, 1977. Durán Ribera y Pinckert, 1988.

7 Lora, 1967: 257-262. Ferreira, 1997: 23-45. Molina Saucedo, 2012.

8 Romero Pittari, 1985: 163-180.

9 Moreno, 1983: 61-65. Romero Pittari, 1985: 163-180. Pittari se apoya en las aseveraciones de Rene Moreno referidas al periodo colonial, extendiéndolas automáticamente al siglo XIX.

${ }^{10}$ Kramer, 1898. Sanabria Fernández, 1977. Durán Ribera y Pinckert, 1988. Molina Saucedo, 2012. Romero Pittari, 1985: 163-180. 
de la acción armada. El interés fundamental de esta investigación es mostrar a la violencia política como un medio, a veces complementario y a veces fundamental, de la acción colectiva para la generación del cambio político. En el caso concreto de este episodio revolucionario, dicho cambio es asumido como el retorno idealizado a un modo de vida, a un sistema de relaciones sociales e intercambios económicos anteriores al proceso librecambista, representado en el imaginario colectivo como «tiempo sin conflictos» y de «equidad social», pero descrito con el discurso del socialismo europeo y transformado a partir de dicha narrativa. En consecuencia, la violencia desplegada en los procesos electorales y en el experimento federalista se interpreta como una estrategia de reafirmación regional y de negociación con el Estado en la que se erige como una nueva práctica del dialogo del centro con regiones.

\section{EL CONTEXTO CRUCEÑO PRERREVOLUCIONARIO}

La región de Santa Cruz contenía diversas peculiaridades: la mayor era el clima de la relativa igualdad y homogeneidad de la sociedad tradicional que entró en la fase de la descomposición con el triunfo de librecambio en la política boliviana en las décadas de 1860-1870. Desde la Colonia los pobladores gozaban del privilegio de «ser comunes a todos los terrenos» ${ }^{11}$, de manera que, en la práctica, las tierras se ocupaban sin ninguna formalidad, ya que la abundancia de tierras libres y el mínimo flujo de población forastera garantizaban la existencia de tal sistema sin conflictos. Como escribió Gabriel René Moreno: «cada cual se instalaba en el terreno que le convenía hasta concluido su negocio o disuelta su familia. La propiedad raíz, divisible y transmisible no existía en la campaña ${ }^{12}$. Según las actas notariales referidas al período estudiado las únicas propiedades con límites claros y dimensiones determinadas eran los «solares» y terrenos dentro de las ciudades y poblados ${ }^{13}$. En las cercanías de las ciudades las unidades agrícolas también tenían dimensiones claramente delineadas ya que era responsabilidad del cabildo su deslinde. La situación era muy diferente con las «acciones» (principal forma de posesión de la tierra, perteneciente a los labradores), las «estancias» y «haciendas» ubicadas lejos de las poblaciones principales, de las que nunca eran mencionados ni la cantidad de tierra, ni los límites exactos de la posesión. El valor

${ }^{11}$ Viedma, 1836: 79.

12 Moreno, 1983: 61.

${ }_{13}$ Archivo Histórico Documental Hermanos Vázquez Machicado, Santa Cruz, Bolivia (en adelante AHDHVM), caja 163, 1864, fol. 513: 64, 109-111. 
de la hacienda era el ganado, sin embargo en la mayor parte de las compras de las «acciones» apenas se hacía mención al número de las cabezas y a la zona de ubicación ${ }^{14}$. Los cruceños apreciaban sus privilegios en materia de la posesión de la tierra ${ }^{15}$.

Otra peculiaridad la representaba su población. Santa Cruz era una ciudad criolla en la que los descendientes de los españoles predominaban en todas las capas sociales, desde los notables hasta los pobres. La situación comenzó a cambiar a mediados del siglo XIX con el auge de la quina que impulsó la migración a la zona de población perteneciente a las regiones nucleares de Bolivia, los llamados los serranos, en su mayoría mestizos, en gran parte artesanos y pequeños comerciantes dedicados a proporcionar servicios a los extractores de la cascarilla en los bosques locales. En el periodo anterior al de la quina, en los años 1830 Alcides D'Orbingy subrayaba la falta de artesanos en la ciudad de Santa Cruz que con, «excepción de algunos oficios -zapatería, herrería, carpintería etc.», era «exclusivamente agrícola» y no existía «ninguna fábrica de tejidos, ningún taller de cualquier especie que sea» ${ }^{16}$. Sin embargo para la década de 1850 en el departamento había 937 talleres, muchos de ellos chicherías ${ }^{17}$, que informaban de que aproximadamente la tercera parte de la población urbana entraba en las categorías de artesanos y pequeños comerciantes. Pese a que el debacle del negocio de la quina afectó a su economía local y que habría que esperar al nuevo ciclo económico ligado a la exportación de la goma, en torno a 1870 y en comparación con el censo de Dalence (1846) la cantidad de herreros, carpinteros, zapateros, sombreros casi se había duplicado ${ }^{18}$, subiendo el número de habitantes en la ciudad Santa Cruz a 10.288 habitantes, según el Censo del $1880^{19}$.

A finales del siglo XIX, el $60 \%$ de los habitantes eran alfabetos e incluso los pobres sabían leer y escribir ${ }^{20}$ lo que se reflejaba en la cantidad de electo-

${ }^{14}$ AHDHVM, caja 163, 1861, fol. 505: 14-35, 36; 1864, fol. 513: 38, 65, 84, 93-94.

15 Aunque el intendente Viedma a finales de la régimen colonial observó que la ausencia de propiedad privada sobre la tierra impedía el desarrollo de la región, la población local defendía arduamente el principio del acceso libre a la tierra: Viedma, 1836: 79. Lo mismo confirma Dalence para mediados del siglo XIX (Dalence, 1975: 210).

16 D’Orbigny, 1945: 1032.

17 Dalence, 1975: 256 y 258.

${ }^{18}$ En 1880 en la ciudad había 888 jefes de familia artesanos, 1.683 mujeres costureras, 375 comerciantes, 40 abogados, 53 curas, 26 empleados públicos, 10 médicos, 33 juristas y apenas 79 jornaleros. Molina Saucedo, 2012: 31-32.

19 Ibidem: 31.

${ }^{20}$ Ibidem: 19, 31. A mediados del siglo, según Dalence, en el departamento había 91 escuelas, una para cada 838 habitantes, mientras que en La Paz debían conformarse con una cada 8.095 habitantes. Dalence, 1975: 218. 
res: el número regional proporcionalmente más alto del país en comparación con su población. En las elecciones de 1840 participaron en Santa Cruz 1.041 personas, en las de 1855 lo hicieron 1.997 y en las de $18721.578^{21}$. Si se tiene en cuenta que estaba vigente el sufragio censitario que daba representación a través de los padres de familias y atendiendo a los miembros del hogar, su comparecencia en las urnas fue del $60 \%$ de la población ${ }^{22}$. De lo anterior se desprende que artesanos, comerciantes y labradores agrícolas constituían la base de la sociedad civil cruceña.

Ligado a la gran repercusión que tuvo en el Oriente el triunfo de libre comercio en la política económica boliviana, las décadas de 1860 y 1870 estuvieron marcadas por un proceso de fuerte diferenciación social en la región. No solo el libre comercio trajo importantes consecuencias para la sociedad cruceña. También el paulatino e inevitable avance del modelo económico integrado al mercado nacional provocó variaciones en las configuraciones sociales en la medida en que los diferentes grupos y estamentos de la comunidad local que las integraban se vieron afectados por esos cambios. Muchos de ellos estuvieron ligados al comercio controlado por los inmigrados extranjeros y bolivianos de las partes centrales del país que conformaron una nueva clase de los «pudientes», mas tarde llamados los «barones del oriente» ${ }^{23}$, cuya llegada y asentamiento fueron acompañados del aflujo de los otros inmigrados ya mencionados, «los serranos». La clase de los «pudientes» estaba en su mayoría conformada por una elite relacionada con el poder central, no siendo extraño por ello que en las listas de las confiscaciones durante la Revolución Igualitaria, en primer lugar figuran los «pudientes», los rematadores de impuestos y los comerciantes ${ }^{24}$.

En consonancia con lo anterior, la sociedad se fue haciendo más heterogénea y más conflictiva. La presencia de nuevos colectivos, unida a los proyectos de colonización promovidos por los «barones del oriente», provocaron

${ }^{21}$ Irurozqui, 2000: 233.

${ }^{22}$ En el registro cívico del 1877 de la ciudad de Santa Cruz estaban inscritos 3.237 ciudadanos, o sea prácticamente toda la población masculina adulta. Defensa de la revolución, 1877: 57.

${ }^{23}$ AHDHVM, Libro copiador de las jefaturas superiores políticos y militares de república (en adelante LC), 1876: 53. Kramer, 1898: 108. En los documentos relacionados a las actas de la Revolución igualitaria encontramos las listas de los comerciantes gravados con imposiciones forzosas. Ahí están tanto bolivianos, como los extranjeros, la casa comercial del argentino Ángel Costas, también la del austriaco Kronemboldt. También en esta época en la ciudad operan comerciantes alemanes Alberto Natusch y Jorge Banzer, fundadores de dos familias oligárquicas cruceñas, cuyos descendientes llegaron a ser presidentes del país (Soruco, 2008: 18).

${ }^{24}$ AHDHVM, LC, 1876: 54, 124-128, 160, 162, 166, 167, 185. 
reacciones negativas por parte de la población local que veía amenazados sus privilegios en lo tocante a la posesión de la tierra: uno de los ricos comerciantes nacido en Trinidad, pero formado y enriquecido en La Paz, futuro magnate de goma Antonio Vaca Diez se convirtió en una figura clave de la elite cruceña, él y Suarez Arana, promovieron los proyectos de la colonización ${ }^{25}$. A esa amenaza se sumó el endeudamiento por parte de los pobladores locales como resultado del creciente consumo de las mercancías llegadas del centro de Bolivia y de las importaciones extranjeras. En las actas notariales figuran numerosos documentos de embargo o de venta de propiedades de «labradores» por las deudas a los «propietarios» y a los comerciantes ${ }^{26}$. Su endeudamiento y, más aún, el despojo por adeudo de sus antiguas propiedades generó empobrecimiento y descontento sociales, agravados por una creciente falta de tierra en el cercado que empujaba a los labradores a buscar nuevas «estancias» en las zonas más lejanas ${ }^{27}$. El desmantelamiento del equilibrio en la sociedad tradicional a partir de un proceso acumulativo desigual fue, así, una combinación de fenómenos socio-económicos en diferentes esferas; de manera que las tensiones en el campo, el empobrecimiento y endeudamiento de los artesanos, e inclusive de parte de la elite, o el golpe del librecambio a la producción artesanal favorecieron la generalización de la protesta y del clima de rebeldía en la mayoría de los cruceños.

La destrucción de la sociedad tradicional cruceña como premisa del surgimiento del movimiento igualitario, ha sido apuntada por varios investigadore ${ }^{28}$. Sin embargo, hace falta precisarla y caracterizarla a partir de la combinación de dos procesos paralelos: de un lado, el ya mencionado malestar de la parte de la elite local relacionada con los labradores en defensa de las antiguas formas y privilegios de posesión de la tierra; y de otro, la agitación de la plebe urbana, en su mayoría de la clase artesana, empobrecida y amenazada por el auge del comercio libre. Al escenario prerrevolucionario hay que añadir la progresiva presencia estatal en regiones periféricas como el Oriente boliviano, donde la autoridad central había estado representada por unos pocos funcionarios públicos y militares. Ello había provocado que las responsabilidades políticas

25 Soruco, 2008: 18. Estatuto de la compañía oriental, 1877.

${ }^{26}$ AHDHVM, caja 163, 1861, fol. 505: 17, 18, 35, 36, 39. Los periódicos estaban llenos de anuncios y llamados de las casas comerciales a sus clientes con pedidos de cancelar sus deudas. Estrella del Oriente, Santa Cruz, 1 de febrero, 1864.

${ }^{27}$ La Estrella del Oriente, Santa Cruz, 14 de marzo, 1864. Era uno de sus motivos de la oposición del Movimiento Igualitario a los comerciantes, los capitalistas que absorbían la mayor parte del fruto de trabajo de los labradores y artesanos. El Semanario, Santa Cruz, 21, 25 de septiembre, 4 de octubre, 1873.

${ }^{28}$ Romero Pittari, 1985. Molina Saucedo, 2012. 
recayeran tradicionalmente en órganos del poder local como la municipalidad. Además, la situación de región de frontera frente a «los indios chiriguanos y otros salvajes ${ }^{29}$ y la necesidad de proteger estancias y el ganado hacían imprescindible el uso de armas en el modo de vida de los cruceños, que vivían una especie de «democracia armada» ${ }^{30}$. Sin embargo, esa situación se vio afectada por los cambios poblacionales y económicos ya señalados en la medida en que favorecieron el crecimiento del aparato burocrático y su consecuente intromisión en los asuntos locales, antes autoregulados por los ciudadanos ${ }^{31}$. A partir de las décadas de 1860 y 1870 esta ingerencia del Estado a los asuntos locales tomó, en muchas ocasiones, formas arbitrarias y controvertidas. De un lado, las autoridades centrales contemplaban los recursos de tierra libre como una fuente de posibles ingresos y ponían en venta las tierras baldías; lo que provocaba malestar entre los labradores por considerarlo un atentado contra sus privilegios ${ }^{32}$. De otro, el gobierno central quiso poner bajo su control a los órganos autogestionarios locales, como la municipalidad. Ello se convirtió en uno de los asuntos críticos del conflicto durante el movimiento igualitario, además de las tentativas de imponer las candidaturas de los diputados para los puestos del poder local ${ }^{33}$. Como se verá a continuación, la desafección local a los cambios socio-económicos y administrativos encontró expresión y voz en el socialismo romántico; lo que en un contexto de relativa homogeneidad racial permitió una notable imbricación y comunicación ideológicas entre los sectores populares y los líderes ilustrados igualitarios.

${ }^{29}$ Dalence, 1976: 310-311.

${ }^{30}$ Irurozqui, 2011c. A partir de textos de la época Marta Irurozqui señala que la democracia se tipificaba de dos modos: «democracia pacífica y democracia armada». La primera estaba referida a las transformaciones del orden político por parte de la sociedad a través de los comicios populares, las asociaciones, la prensa. La segunda hacía mención al poder marcial desplegado por el pueblo cuando la ley en tanto expresión de su voluntad soberana era vulnerada. El recurso a la fuerza por parte de la población era un derecho y un deber constitucionales a ejercerse únicamente como remedio extremo cuando los mecanismos asociados a la democracia pacífica ni impedían o neutralizaban los abusos de poder ni tampoco aseguraban la responsabilidad de los gobernantes respecto a sus representados.

31 Rossana Barragán indica que en este período la cantidad de los funcionarios se triplicó (Barragán, 2000: 30).

32 Informe al Secretario General del Gobierno, 31 de mayo de 1871, Archivo Nacional de Bolivia, Sucre, Oropeza, Departamento de Chuquisaca, Bolivia (en adelante ANB), Ministerio del Interior (en adelante MI), 1871, tomo 195, $\mathrm{n}^{\circ} 89$.

${ }^{33}$ Barberí, 1870. 
En torno al periódico La Montaña, cuyo primer número fue publicado el 26 de marzo del 1864, se formó un grupo político, cuyo nombre aludía a los jacobinos franceses. El mismo fue creado por Carlos Melquíades Barberí, uno de los fundadores y principales promotores del Club de la Igualdad en la década de los 1870. Este periódico seguía a Lamennais y declaraba su adhesión al socialismo cristiano $^{34}$. La defensa del pobre, de sus derechos políticos y sociales, también representó el tema de otro periódico, La Estrella del Oriente, igualmente de tendencia socio-liberal. En julio de 1864 publicó en sus páginas un vasto artículo en el que con mucho detalle se discutían y comparaban las ideas de Fourier y de Proudhon y se describía un falansterio. A ello se sumaban comentarios sobre otros socialistas franceses (Luis Blanc, Pierre Leroux, Étienne Cabet ${ }^{35}$ ) que testimoniaban de un alto nivel de conocimiento de los intelectuales cruceños acerca del pensamiento socialista. Los sentimientos deprimidos de la antigua igualdad propios de los cruceños parecían encontrar un eco acogedor en las ideas socialistas. En contrapartida, los publicistas de derecha, miembros del Club Patriótico, acusaban a La Montaña «de suscitar la guerra de clases, concitando odios inmotivados entre los de levita y los de chaqueta, para establecer una división funesta y desconocida hasta hoy en el país y fundar una igualdad, desconocida aun entre los salvajes ${ }^{36}{ }^{36}$. La actividad de La Montaña y La Estrella del Oriente fue el germen que diez años más tarde daría lugar a la formación del movimiento igualitario.

Aunque el golpe de Estado de Mariano Melgarejo en diciembre de 1864 obligó a la sociedad cruceña a sumirse temporalmente en una aparente somnolencia política, pudo salir de ella gracias a la reorganización del grupo político antes mencionado, esta vez organizado en torno a Andrés Ibáñez, un nuevo líder carismático, muy popular en las masas cruceñas, quien, junto a su padre Francisco, protagonizó la sublevación contra la dictadura de Melgarejo en $1870^{37}$ a través de la formación del batallón popular «La Libertad». Después de la victoria de los revolucionarios dicho batallón fue disuelto por las autoridades, pero esta orden nunca fue acatada ni entregadas las armas ${ }^{38}$. Ibáñez desde su primera aparición en el escenario político se apoyó en un grupo armado.

\footnotetext{
${ }^{34}$ La Montaña, Santa Cruz, 26 de marzo, 1864.

${ }^{35}$ La Estrella del Oriente, 11 de julio, 1864.

${ }^{36}$ El Independiente, Santa Cruz, 9 de enero, 1864.

${ }^{37}$ La sublevación protagonizada por La Paz, englobó otras partes del país, incluyendo Santa Cruz. Véase Irurozqui, 2007.

${ }^{38}$ El Doctor Andrés Ibáñez, 1872: 2.
} 
Derrocada la dictadura, nuevos políticos con un discurso socio-liberal intervinieron como candidatos a diputados en las elecciones del 1871 mostrándose en todo momento partidarios del secretario general del gobierno, Casimiro Corral, reconocido líder de la plebe paceña. Además de Andrés Ibáñez, quien en la lucha electoral criticó la explotación del pueblo por parte de la elite criolla, comparándola con el yugo del imperio turco, estaban Carlos Melquiades Barberí y Ramón Roca. Este último fue quien promovió la elección general de todos los empleados públicos por el pueblo, la federación y el voto univer$\mathrm{sal}^{39}$. Pese a que estos candidatos perdieron las elecciones frente al conocido intelectual Mamerto Loyola que obtuvo 1.017 votos, demostraron un éxito relativo materializado en los 335 sufragios de Barberí y los 288 de Ibáñez ${ }^{40}$. Ello les permitió convertirse en la base del futuro movimiento igualitario. Mientras Ibáñez con su gente del ex batallón «La Libertad» conformaba el brazo armado del grupo, Barberí, merced a su popularidad en la ciudad, fue electo presidente de la municipalidad cruceña. Ambos constituían los motores principales de un naciente movimiento civil que combinaba una actuación pacífica en el marco municipal y una disposición a la defensa armada. Asimismo, Barberí, Ibáñez y sus correligionarios trajeron a la política cruceña un nuevo discurso ligado al liberalismo social de Casimiro Corral: hablaban en nombre de todo el pueblo «sin chaqueta», labradores, propietarios, artesanos, haciendo hincapié en la explotación y rapiña capitalista ${ }^{41}$. Desde 1872, Ibáñez, Barberí y Antonio Barba editaban el periódico El Eco de la Igualdad que se convirtió en el centro de formación del Partido Igualitario. Aunque hasta ahora no hay datos sobre los lazos orgánicos entre este grupo y el Partido Corralista, los igualitarios en varias ocasiones se reconocían parte del mismo ${ }^{42}$. Uno de los puntos más importantes del pensamiento de Corral que atraía a los igualitarios era su tesis acerca de que la base de todo ascenso social residía en el trabajo, siendo las «clases laboriosas» la base más sana de la sociedad ${ }^{43}$.

Las campañas electorales de 1872 y 1874 significaron un momento crucial en la formación del movimiento igualitario. Para las autoridades cruceñas el grupo de Ibáñez era una revoltosa facción del corralismo paceño que ya había demostrado su fuerza en varias asonadas revolucionarias. Si bien como se acaba de señalar los igualitarios nunca parecieron mantener una relación orgánica con esa formación política, sí funcionaron como aliados ideológi-

\footnotetext{
3 Roca, 1871.

40 Elecciones, 11 de mayo de 1871, ANB, MI, 1871, tomo 195, nº 89.

${ }^{41}$ El Semanario, 21 de septiembre, 1873.

${ }_{42}$ ANB, MI, 1871, tomo 834, n 805: 2.

${ }^{43}$ Véase sobre Corral: Irurozqui, 2001: 414-417.
} 
cos circunstanciales. Los comicios presidenciales celebrados en la ciudad de Santa Cruz en marzo de 1873 demostraron la fuerza del Partido Corralista que ocupó el segundo lugar después del Partido Rojo en el gobierno, cuyo candidato, Adolfo Ballivián, obtuvo 445 votos frente a los 425 ganados por Corral de un total de 943 sufragios $^{44}$. De ahí que ser igualitario en Santa Cruz se leyera como ser corralista a nivel nacional, siendo ambos partidos tildados de comunistas. Sin embargo, a juzgar por el discurrir de ambas agrupaciones, igualitarios y corralistas tuvieron completa autonomía y su propia lógica de la evolución ideológica y política.

En las elecciones al Congreso del 1874, Ibáñez compitió con Antonio Vaca Diez, un representante de la nueva elite local formada por los grandes comerciantes, magnates de goma, nuevos propietarios de tierra y de los futuros enormes latifundios en el Oriente boliviano. La campaña electoral Ibáñez se identificó completamente con las mayorías cruceñas. En los fastos electorales quedó registrado un gesto expresivo de Ibáñez al respecto. Durante su discusión con un contrincante en la plaza principal, se quitó la levita y se retiró caminando descalzo rodeado por artesanos. En una hoja impresa en Santa Cruz que daba cuenta de estos acontecimientos se contaba que «el lunes se presentó el populacho encabezado por Dr. Andrés Ibáñez, y dos o tres más, una vez en la plaza, y después de algunos discursos y vítores al Dr. Corral, a los cholos, etcétera, y mueras a los ricos y a los nobles, arrojan las levitas y se ponen chaquetas y continúan su paseo por las calles» ${ }^{45}$. Otro líder del grupo, Barberí, repitió el gesto de Ibáñez, pronunciando una nueva consigna: «todos somos iguales». Este gesto de Ibáñez y Barberí simbolizaba ${ }^{46}$ la ruptura de una parte de la elite con los «pudientes», o sea con aquel sector de la elite local que ya no figuraba como integrante de la sociedad urbana tradicional. Según el mismo relato, por la noche cuando Ibáñez penetró en el cuartel para agitar a los soldados fue acompañado de una muchedumbre que daba Vivas a Ibáñez y a Corral. El Mayor de la Plaza intervino para persuadirle de abandonar el cuartel y declarar su respeto a los resultados de las futuras elecciones $^{47}$. Aunque Ibáñez lo aceptó, su actuación mostraba que en la compaña electoral no descartaba el uso de la fuerza, siendo su esfuerzo de conquistar las simpatías de la tropa de guarnición el modo de neutralizar el favor del ejército al partido oficial. Dos días más tarde de lo relatado, Ibáñez fundó

${ }^{44}$ ANB, MI, 1871, tomo 199, no 35.

45 ANB, MI, 1871, tomo 834, $\mathrm{n}^{\circ}$ 805: 2.

${ }^{46}$ Este gesto corresponde a lo que Norbert Elias llamó «el fetichismo del prestigio» propio para cualquier grupo de la elite. Elias, 2002: 129.

${ }^{47}$ ANB, MI, 1871, tomo 834, nº 805: 3-4. 
el Club de la Igualdad, que declaró que «no debe haber distinción de clases, nada de ricos, ni de pobres» ${ }^{48}$.

La presidencia del Club estaba compuesta por los viejos partidarios de Ibáñez y Barberí, el cura Manuel A. Castedo, Antonio Vicente Barba, José Mariano Durán Canelas ${ }^{49}$ y Mariano Vargas ${ }^{50}$. A esos había que añadir otros líderes como el cura Efrain Barberí (considerado cabecilla de los comunis$\operatorname{tas}^{51}$ ) y el periodista Pedro Manuel Silva. Todos ellos pertenecían a familias acomodadas de la ciudad y representaban a la elite tradicional cruceña de propietarios, estancieros y abogados, en la que Barberí, Durán, Barba o Silva, en calidad de doctores, actuaban como influentes líderes de la opinión pública. De hecho, Ibáñez pertenecía a una respetada familia criolla de hacendados con propiedades en Santa Cruz y Cochabamba, a una élite cruceña en descenso, los labradores-propietarios que debían ceder su lugar ante el ascenso de nuevos ricos, los «pudientes», la elite agraria-comercial y gomera, ligada con los capitales y redes comerciales internacionales, cuyo ejemplo más representativo era la casa de Suarez Arana. Ibáñez era, así, una encarnación de la vieja elite local, de la capas medias y bajas, de la figuración mitificada de las mayorías cruceñas, de la parte la elite que compartía con propietarios, artesanos, labradores sus desilusiones y descontento por los cambios ocurridos en el país, y que sentía sus privilegios y costumbres de posesión de la tierra amenazados por comerciantes y propietarios de nuevo cuño, algunos emigrados de otras partes del país. Los líderes de los igualitarios, como Barberí y Silva, supieron acoplar discursivamente las ideas del socialismo romántico a su característica conformación local y social. Y lo hicieron de manera tal que las posiciones de esta fracción de la elite cruceña se fortalecieron al solidarizarse con la mayoría popular descontenta, al saber representarla en lo político y social y al capitalizar su fuerza, siendo su base de apoyo «la clase artesana, la mayoría de este pueblo» ${ }^{52}$. El empobrecimiento y decaimiento social de la parte de la elite y de las masas plebeyas actuó de factor de unión social y conformación de una nueva unidad política, articulada en torno al sentimiento de la pérdida paulatina de los derechos antes inalienables a la tierra libre ${ }^{53}$. Ese argumento

48 El Semanario, 21 de septiembre, 1873.

49 Destacado dramaturgo e historiador cruceño.

50 Manifiesto del Club de la Igualdad. 13 de mayo de 1876, ANB, MI, 1871, tomo 836: 601.

${ }^{51}$ AHDHVM, LC, 1876: 30.

${ }^{52}$ Luz sobre los sucesos, 1876: 2.

${ }^{53}$ Aún en el 1871 Ibáñez en una de sus proclamas refirió al empobrecimiento de los cruceños causado por los «pudientes» que «a manera de los turcos, empuñan un bastón para arrancar el dinero de las personas, de las propiedades». Andrés Ibáñez, A mis electores, Santa Cruz, 1871, ANB, MI, 1871, tomo 834. 
aunó a muchos cruceños, con independencia del estrato social de pertenencia, en un comportamiento solidario expresado en alistarse a la montonera y apoyar con armas o sin armas a los líderes reconocidos del Club de la Igualdad.

Descentralización y poder municipal ${ }^{54}$ con mayor responsabilidad social eran los puntos claves del programa de los igualitarios que dominaban en el consejo municipal cruceño y pretendían realizar sus ideas a través del mismo, siendo esta institución la protectora de los pobres, el «ángel tutelar de la clase pobre en general, ensanchando la esfera de su acción y estableciendo obras de beneficencia pública» ${ }^{55}$. La municipalidad en los años de 1870 se convirtió en el núcleo de oposición a la presión centralista del gobierno nacional. El conflicto de la municipalidad cruceña con los representantes del poder central, no era único en este momento. Formaba parte de una confrontación más amplia entre los consejos de Cochabamba y La Paz con el ministro Mariano Baptista, relativa a los poderes jurisdiccionales y administrativos de los municipios y ejemplificada en la negativa de los primeros a entregar al gobierno sus fondos. No solo los igualitarios fueron tildados de comunistas, sino que también las municipalidades paceña y cochabambina fueron acusadas en las influencias de la Comuna de Paris ${ }^{56}$. La municipalidad cruceña se convirtió en la portavoz de la mayoría ciudadana, reunida en el Club de la Igualdad.

Ya como uno de los líderes del Club de la Igualdad Ibáñez ganó las elecciones de $1874^{57}$. La presencia de los igualitarios en la ciudad se asentaba en la municipalidad e iba acompañada con un cuerpo armado, siendo trasmitido su mensaje político mediante una retórica cuasi-socialista. Si bien ello contribuyó al reclutamiento de simpatizantes para el partido igualitario, también movió a la autoridad política y militar a reprimir el movimiento bajo el argumento de que Ibáñez preparaba una rebelión comunista. Esa medida se inscribía en la política del presidente Tomas Frías de desarmar la oposición en todas las ciudades del país ante la supuesta amenaza antigubernamental que constituía el Partido Corralista en La Paz. Considerada la «facción de Ibáñez» como el brazo armado corralista en el Oriente, su represión formaba, entonces, parte de una política de desarme de los civiles ${ }^{58}$. Ya en septiembre de 1874, ante la

${ }^{54}$ Sobre otros casos de conflicto y autogestión municipal véanse: Irurozqui 2011a: 274276. Guiteras, 2012: 63-70 y 118-125.

${ }_{55}$ Informe del Prefecto Rafael Peña al Secretario General del Gobierno Casimiro Corral, 10 de abril de 1871, ANB, MI, 1871, tomo 195, nº 89.

56 Méndez, 1874: 9.

${ }^{57}$ En la Asamblea nacional del 1874 Andrés Ibáñez se juntó al grupo corralista.

${ }^{58}$ Véase sobre la política del presidente Frías de desarmar la oposición. Irurozqui, 2011: 91, 130-137. 
negativa de Corral de desarmar a las milicias de los artesanos en La Paz, el gobierno había autorizado tomar por asalto su casa, confiscado las armas y arrestado sus correligionarios. Estos acontecimientos tuvieron un eco en Santa Cruz donde los rivales de los igualitarios apoyaron las medidas del gobierno de Frías, asustados por la retórica revolucionaria del Club, su fuerza armada y su apoyo electoral:

Tal fue el rumor que corrió que a no dudar temblaron acaudalados, por cuya incógnita y apócrifa medida la generalidad creyó que el sistema igualitario no era sino igualar, sacando la mitad de los bienes a los doscientos pudientes que nada más había para darles a los numerosos pobres, de tal manera que la parte de los grandes hombres resolvieron a todo trance se disuelva el partido igualitario y principalmente su jefe ${ }^{59}$.

Ante ello, Ibáñez tuvo que escapar de la ciudad, ocultándose en su finca y luego en la selva, donde se le unió una montonera de los igualitarios formada por doscientos hombres armados. Como la mayoría de los miembros de la Municipalidad de Santa Cruz eran igualitarios, los militares reclamaron la destitución de su presidente Barberí ${ }^{60}$. El conflicto entre el consejo cruceño y el ejército se agudizó con la rotunda negativa del primero de conceder un préstamo para financiar la compaña contra la montonera igualitaria. En este contexto, la prefectura recurrió al uso de la fuerza para no perder el control sobre la ciudad, dando orden a la policía en febrero del 1875 de que allanase todas las casas de los munícipes igualitarios ${ }^{61}$. Esa medida derivó en una violencia abierta en las calles y tiroteos diarios con participación de patrullas de artesanos igualitarios ${ }^{62}$. La rebeldía popular fue la respuesta lógica a la violencia por parte del Estado, representado en Santa Cruz por los militares y los funcionarios asignados por el gobierno central. Este conflicto adoptó formas de violencia debido fundamentalmente a la intransigencia mostrada a las instituciones locales por parte de la alianza de la parte de la elite local, los «pudientes», y la burocracia centralista.

El ambiente hostil hacia los militares y las acciones de la montonera de Ibáñez hicieron que la tropa se sintiese asediada en sus cuarteles. La situación se complicó en marzo de 1875 a raíz del fracaso en La Paz del motín corra-

\footnotetext{
59 Testimonio de un escrito anónimo, llamado Manuscrito Lara, parcialmente publicado por Durán Ribera y Pinckert, 1988: 45.

${ }^{60}$ Carta del comandante Demetrio Urdininea al Fiscal del Partido, 26 de febrero de 1875, ANB, MI, 1875, tomo 202, $\mathrm{n}^{\mathrm{o}} 25$.

${ }^{61}$ El Látigo, Santa Cruz, 15 de febrero, 1875.

${ }^{62}$ Informe al jefe de policía del 4 de marzo de 1875, ANB, MI, 1875, tomo 202, no 25.
} 
lista, llamado «la revolución comunista» ${ }^{63}$, que había sido apoyado en Santa Cruz por los igualitarios. El 27 de abril de 1875, Jueves Santo, la montonera de Ibáñez entró en la ciudad de Santa Cruz, siendo sus filas aumentadas gracias a la deserción de soldados de plaza. El periódico El Cometa describió ese asalto como la acción de un «Club comunista» que «bajo el pretexto de libre asociación trata de imitar a los correligionarios de La Paz [corralistas], debiendo salir en grupo para apoderarse de las armas del cuartel» ${ }^{64}$. Ambas fuerzas se enfrentaron en el campo de Trompillo, en las cercanías de la ciudad. Después de una escaramuza de doce minutos los rebeldes fueron derrotados. Huidos hacia Samaipata, contra ellos marchó una tropa de Vallegrande que el 23 de noviembre los batió en Pozos de los Pororós ${ }^{65}$, pudiendo Ibáñez escapar.

En febrero de 1876, el presidente Frías proclamó la amnistía política y convocó elecciones generales para mayo del mismo año. Ibáñez volvió a Santa Cruz y su casa paterna se convirtió en el Estado Mayor de los igualitarios, donde cada día se reunían numerosos grupos de sus partidarios. Las filas del Club crecían de manera vertiginosa. En abril en la casa de Barberí llegaron a reunirse unas seiscientas personas en un acto en el que fue elegida la junta directiva del Partido de la Igualdad ${ }^{66}$. Estaba encabezada por Barberí, siendo Ibáñez elegido primer vicepresidente. Los igualitarios establecieron una nueva estructura del partido, que puede considerarse como uno de los primeros intentos en Bolivia de organizar un sistema territorial de militancia. La ciudad fue dividida en cuatro barrios, al frente de cada uno estaban dos activistasdirigentes con la obligación de mantener la comunicación con todos miembros y simpatizantes del partido: debían informarles sobre todas las decisiones de la junta directiva y reunirlos en las asambleas masivas celebradas en la casa de Barberí ${ }^{67}$.

En las elecciones presidenciales anunciadas por Frías, José María Santiváñez del Partido Rojo y respaldado por el Ejecutivo se enfrentó con Hilarión

${ }^{63}$ Se trata de la rebelión corralista en La Paz, cuando los sublevados asediaron el Palacio del Gobierno que fue quemado (a partir de ahí se llama Palacio Quemado), a los corralistas los acusaron en tentativa establecer «la comuna» siguiendo ejemplo de la parisina La Reforma, La Paz, 24 de marzo, 1875.

${ }^{64}$ El Cometa, Santa Cruz, 8 de mayo, 1876.

${ }^{65}$ El Eventual, Santa Cruz, 13 de diciembre, 1875. Contra 66 rebeldes se enfrentaron 81 soldado. Los soldados del gobierno tuvieron 8 muertos y 14 heridos, mientras los rebeldes dejaron en el campo de batalla 6 muertos, 3 heridos.

${ }^{66}$ El Estandarte del pueblo, Santa Cruz, 26 de abril, 1878. Nos parece exagerado el numero de los reunidos, lo mas correcto considerar el número de los adherentes al Club por las cantidad de firmas bajo sus llamados y manifiestos, que oscila entre 180 a 200.

${ }^{67}$ El Estandarte del pueblo, Santa Cruz, 26 de abril, 1878. 
Daza y Jorge Oblitas. Este último retiró su candidatura y apoyó a Daza como único líder opositor. En un inicio Ibáñez había optado por Oblitas, por ser «amigo de los corralistas», pero tras su renuncia el Partido de la Igualdad apoyó a Daza como opositor de los rojos ${ }^{68}$. En caso del triunfo de Daza, los igualitarios aspiraban a obtener el control sobre el departamento como premio por su apoyo. En el proceso electoral, los igualitarios proclamaron que su verdadera meta consistía en la «defensa de los pobres», del pueblo compuesto de labradores y artesanos, y en el desarrollo en nombre de la equidad de un nuevo sistema de poder, del self-government (autogobierno) ${ }^{69}$; de la descentralización y la municipalización de Bolivia $^{70}$.

A finales de marzo de 1876 los liberales del Club Democrático, compuesto de los artesanos y pequeños comerciantes, extranjeros y migrantes, propusieron una alianza con el Partido de la Igualdad. La reacción de los igualitarios fue ambivalente. Al «Club Democrático» lo apreciaban como una agrupación «cercana», pero «no fraternal» debido a que estaba compuesta por «judíos y masones». Además, los demócratas reunían en sus filas a los comerciantes y artesanos extranjeros ${ }^{71}$. Ello no solo les hacía desconfiables a ojos de los cruceños, celadores de la religiosidad y privilegios locales, sino que contradecía al discurso de los igualitarios y de su imaginario colectivo, basados en la xenofobia y el particularismo. Si bien ello impidió la formalización de una alianza abierta entre ambos partidos, no evitó que el Partido de la Igualdad se tornase en una fuerza hegemónica que atraía numerosos aliados debido a considerársela la única fuerza capaz de afrontar a los «pudientes» o nuevos ricos apoyados en las autoridades centrales.

El 4 de mayo de 1876, el general Daza, favorito de la campaña electoral, dio un golpe de Estado y se proclamó Presidente. A Santa Cruz estas noticias llegaron con retraso y las elecciones se realizaron en el día previsto. Daza -el candidato de los igualitarios- obtuvo la victoria absoluta: 1.133 votos contra los 217 del candidato de los rojos ${ }^{72}$. Si bien Ibáñez y sus seguidores podrían haber esperado ser reconocidos y apoyados por el nuevo presidente, las designaciones de Demetrio Roca como prefecto y del coronel Ignacio Romero como el comandante indicaban lo contrario, ya que ambos eran enemigos de Ibáñez ${ }^{73}$. De hecho, el nuevo comandante cerró las sesiones del Club de Igualdad y

\footnotetext{
${ }^{68}$ Manifiesto del Club de la Igualdad, 13 de mayo de 1876, ANB, MI, 1876 tomo 836: 601.

${ }^{69}$ El Estandarte del pueblo, 18 de abril, 1876.

70 El Demócrata, 4 de mayo, 1876.

${ }^{71}$ El Estandarte del pueblo, 26 de abril, 1876.

${ }^{72}$ El Club Constitucional, 12 de mayo, 1876.

${ }^{73}$ Defensa de la revolución, 1877: 8.
} 
tomó preso a su presidente Barberí como prueba de que las autoridades estaban decididas a acabar con la formación igualitaria. A esas medidas se sumó una petición interpuesta por el prefecto al gobierno central llamándolo disolver el consejo municipal, dominado por los igualitarios-comunistas. Si esa petición fue apoyada por 140 firmas de los vecinos, la escrita en protesta a favor de los igualitarios fue signada por 1.135 ciudadanos $^{74}$. Pese a ello, en agosto de 1876, Daza atendió la demanda del prefecto y entregó el poder municipal al consejo departamental. Ante ello Ibáñez envió una furiosa carta de protesta al presidente: «la suspensión de la municipalidad es privar al pueblo de la protección natural que ejerce en favor de los intereses materiales y sociales de esta capital» ${ }^{75}$. La rivalidad abierta de las nuevas autoridades hizo que Ibáñez se refugiara en el campo junto a sus partidarios.

Como la formación de Ibáñez seguía siendo el partido con más adeptos en la ciudad, siendo difícil el control del departamento sin la neutralización de su líder, el gobierno le envió una carta llena de lisonjas y propuestas de colaboración, tras la que Ibáñez pudo regresar a Santa Cruz siendo recibido con júbilo por sus habitantes. Las palabras de bienvenida del gobierno duraron poco ya que, tras transcurrir algunos días, la medianoche del 29 de agosto Ibáñez fue arrestado en nombre de la seguridad del departamento. El jefe militar Romero explicó la necesidad de su arresto por las presuntas reuniones de la gente armada de Ibáñez en la localidad de Cotoca donde preparaban el asalto a los cuarteles con la aquiescencia de algunos militares ${ }^{76}$. Después de su arresto y de que «fuera de la prisión se persiguieron a casi todos los honrados artesanos que figuraban notablemente en el Club de Igualdad», los desordenes y refriegas en las calles se hicieron diarios ${ }^{77}$. El 12 de septiembre los igualitarios debían hacer la entrega voluntaria de sus armas, pero la orden no fue acatada. El prefecto decidió entonces preparar un grupo de soldados para escoltar a Ibáñez a La Paz, algo que tuvo de nuevo que posponer por miedo de los igualitarios armados ${ }^{78}$. Y no se trataba de temor infundado ya que éstos habían desarrollado una labor propagandística dentro de la guarnición, la denominada «columna del orden», aprovechando su descontento ante los impagos de salario ${ }^{79}$.

${ }^{74}$ Ferreira, 1997: 26.

75 Sociedad de Igualdad al Poder ejecutivo, 12 de agosto de 1876, ANB, MI, 1876, tomo $203, \mathrm{n}^{\circ} 189$.

${ }_{76}$ AHDHVM, LC, 1876: 15.

77 Luz sobre los sucesos, 1876: 14.

78 AHDHVM, LC, 1876: 16.

${ }^{79}$ Molina Saucedo, 2012: 83. 


\section{La Revolución de la Igualdad y la Proclama de la Federación}

La noche del 1 de octubre de 1876 la guarnición se sublevó exigiendo la cancelación de los salarios adeudados. Romero decidió aplastar el motín pero la soldadesca lo recibió con vivas a Ibáñez. Sumido en cólera, el comandante de la plaza mató a un oficial e hirió a dos soldados sublevados. Ello le costó la vida. Cuando los habitantes de la ciudad escucharon el tiroteo, pensaron que se trataba de la ejecución de Ibáñez y se dirigieron hacia la Plaza. El motín militar se convirtió en una sublevación popular, Ibáñez fue liberado. Al día siguiente, se reunieron setecientas personas que firmaron la documentación que legitimaba la asonada y daba a Ibáñez el cargo de prefecto del departamento y comandante de la tropa ${ }^{80}$. Más tarde, en la casa del rico propietario José Torres se reunió un grupo de vecinos con el objetivo de buscar un entendimiento con Ibáñez. Proponían juntar entre los propietarios la suma necesaria para pagar el «chancelo» ${ }^{81}$ a los soldados si Ibáñez aceptaba abandonar el poder ${ }^{82}$. Pero éste tenía otros planes. El día 3 de octubre hizo un llamado a los habitantes de Santa Cruz que devino en el programa de la revolución:

La igualdad con la propiedad, es el desiderátum de la ventura de los pueblos. Esforcémonos por aproximarnos a él, y nos presentaremos más dignos ante toda la Nación ${ }^{83}$.

Esta proclama fue la respuesta al acuerdo buscado por la junta de vecinos. En ella no se llamaba a la plebe para iniciar el saqueo y reparto de las riquezas de la ciudad, sino que se proponía un programa de regeneración del antiguo sistema de la propiedad libre consistente en el libre acceso a la tierra («la igualdad en propiedad») y de limitación de la «rapiña capitalista» del comercio libre. Expresaba el sueño de retornar a la sociedad armónica y sin conflicto de la antigua Santa Cruz. Esta etapa inicial de la revolución caracterizada por el intento de realizar los idearios de los igualitarios duró hasta finales del año 1877 , haciendo poco a poco visibles el menor interés del movimiento por los lemas ideológicos declarados y su creciente preocupación por legalizar su poder y llegar a un arreglo con el gobierno nacional.

Como las deudas salariales a los soldados habían motivado su levantamiento el 1 de octubre, el día 9 del mismo mes Ibáñez llamó a una reunión

80 AHDHVM, LC, 1876: 185.

${ }^{81}$ Así se llamaba al salario militar.

82 AHDHVM, LC, 1876: 185.

83 Proclama a los habitantes del departamento, 3 de marzo de 1876, ANB, MI, 1876, tomo $837, \mathrm{n}^{\mathrm{o}} 32$. 
popular para resolver el problema del pago de esa deuda. Con esta consulta, Ibáñez dejaba constancia de su creencia relativa a que el poder tenía que afirmarse mediante la discusión de los principales asuntos de la vida citadina en asambleas populares. Ibáñez y sus partidarios pidieron allí a la población que contribuyera al pago de los salarios con aportes voluntarios ${ }^{84}$. En una ciudad relativamente pequeña lograron recolectar 1.500 pesos $^{85}$, que no fueron suficientes. Por ello y para dejar claro su agradecimiento a los militares que lo habían liberado de la prisión, Ibáñez decidió decretar préstamos forzosos. La suma de las recaudaciones llegó a los 48.110 pesos, cuya mayor parte provenía del cobro de impuestos a comerciantes y estancieros y del diezmo a cuenta de futuros ingresos ${ }^{86}$. Esas medidas iniciaron una cascada de disidencias dentro del Club. El 22 de diciembre de 1876 Carlos Melquíades Barberí publicó un impreso mediante el que se desligaba del movimiento y anunciaba el abandono de la política ${ }^{87}$. Barberí representaba el sector intelectual del Club, que se empapaba en las ideas del socialismo europeo. La llegada al poder y las medidas violentas que reprimían parte de la población cruceña no concordaban con su concepto y fueron la causa de su retirada. Este hecho, sin duda, debilitó el movimiento dándole un impulso de desarrollo hacía una rebelión plebeya tradicional.

La reacción inicial del presidente Daza ante lo sucedido en Santa Cruz fue de expectativa. El periódico oficioso La Reforma se limitó a informar sobre los acontecimientos del 1 de octubre interpretándolos como una riña personal entre Ibáñez y el comandante Romero, subrayando que en el departamento reinaba la paz y tranquilidad ${ }^{88}$. Solamente en un mes después de la revolución los periódicos publicaron el manifiesto de Ibáñez del 3 de octubre con la famosa frase sobre la igualdad en la propiedad ${ }^{89}$. Si bien a partir de ello los cruceños rebeldes fueron mirados por las autoridades con mayor preocupación, el apoyo de los ciudadanos armados y de la tropa a la revolución contra los abusos de los gobernadores locales hizo que Daza aceptara los cambios políticos en Santa Cruz. Asumía que lo ocurrido en ese departamento no era algo excepcional en la política boliviana, minimizándolo con la interpretación de que se trataba de un asunto de rivalidad personal a nivel local. En su opinión ello quedaba confirmado en el hecho de que Ibáñez acataba la designación

${ }^{84}$ AHDHVM, LC, 1876: 35-39.

${ }^{85}$ Durán Ribera y Pinckert, 1988: 103.

86 AHDHVM, LC, 1876: 35.

87 Sanabria Fernández, 1977: 29.

${ }^{88}$ La Reforma, 18 de octubre, 1876. Los 17 días eran necesarias para que las primeras noticias sobre la revolución en Santa Cruz llegasen a La Paz.

${ }^{89}$ La Reforma, 1 de noviembre, 1876. 
del general Juan José Pérez ${ }^{90}$ como nuevo prefecto. Sin embargo, el asunto no iba a ser tan fácil. Apenas había llegado Pérez al departamento, recibió el 11 de diciembre en Samaipata una carta de Ibáñez con una serie de condiciones para dejarle asumir su cargo: la designación de Pérez tenía que estar ratificada por una comisión formada por una junta de vecinos; los militares que no se adhirieran a la revolución del 1 de octubre tendrían que abandonar el departamento; Pérez debía reconocer la legitimidad de todas las acciones de Ibáñez como prefecto, incluyendo los gastos; y las autoridades tenían que revocar todas las medidas represivas contra el Club de la Igualdad ${ }^{91}$. Si bien Pérez aceptó todas las condiciones que garantizaban a Ibáñez un poder real en Santa Cruz, Ibáñez decidió proteger su gobierno de la intervención de las autoridades nacionales proclamando la federación.

Los igualitarios y los soldados se sublevaron nuevamente el día de la Navidad de 1877. Llamaron a una asamblea popular, a la que «invitaron» a los notables de la ciudad. En ella, Ibáñez ya no habló sobre la igualdad social o sobre la equidad en la distribución de las riquezas, sino del olvido de las tierras orientales por parte del gobierno nacional y sobre los defectos de la República unitaria. Al finalizar su disertación, Ibáñez proclamó la Federación. En esta asamblea, se organizó la Junta Superior del Estado Federal del Oriente y Pérez fue apartado del mando ${ }^{92}$. Se iniciaba así una nueva etapa de la revolución igualitaria, caracterizada por la convergencia hacia formas tradicionales de rebelión regionalista a través de consignas federalistas y por la retirada de sus líderes intelectuales ante la devaluación ideológica y moral del movimiento.

Los sentimientos federalistas siempre habían estado muy arraigados en Santa Cruz. Uno de los líderes de los igualitarios, Carlos Melquíades Barberí, ya en 1864 había publicado un proyecto de constitución federal de Bolivia que proponía la división del país en seis distritos federales y la entrega de más poder al nivel local. El proyecto de Barberí podría calificarse de moderado: su federación mantenía el centralismo aunque con mayor autonomía municipal y regional a la existente y con un espíritu basado en la justicia y equidad sociales ${ }^{93}$. Al constituirse el Club de Igualdad las consignas de federación desaparecieron de las proclamas y discursos de los igualitarios. La proclama de la federación por Ibáñez en diciembre de 1876 fue una reacción de los

\footnotetext{
${ }^{90}$ Pérez era un federalista moderado, lo que debería ayudar a encontrar el consenso entre rebeldes y las autoridades centrales.

${ }_{91}$ Carta de Andrés Ibáñez al general Juan José Pérez, 11 de diciembre 1876, ANB, MI, 1876, tomo 203, $\mathrm{n}^{\circ} 37$.

92 Romero Pittari, 1985: 174-175. Durán Ribera y Pinckert, 1988: 120-125. AHDHVM, LC, 1876: 185-186.

${ }^{93}$ La Estrella del Oriente, 14 de marzo, 1864.
} 
igualitarios contra el rechazo de Daza a reconocerle y confiarle el gobierno de Santa Cruz. Una vez proclamada la federación el recrudecimiento del discurso particularista y nacionalista cruceño fue inevitable, como también lo fue el recurso a la violencia como forma de defender lo particular y lo suyo frente a otras partes del país. Ante la amenaza que esto representaba para el gobierno, Ibáñez esperaba que Daza careciera de la fuerza suficiente para enviarla a una zona tan lejana como Santa Cruz, donde ya su movimiento había demostrado las posibilidades de resistencia armada de las montoneras; y que, de cara a una futura negociación, ello le permitiera ganar tiempo para hacerse más fuerte en el departamento. Con ese objetivo y consciente de que solo la provincia de Chiquitos había apoyado a la Federación, Ibáñez organizó una expedición militar a Vallegrande. El 26 de enero salió de Santa Cruz con su tropa y nombró como comandante interino al «paraguayo» Manuel María Fabio, instalado en Santa Cruz después de la guerra de la Triple Alianza. Para evitar contratiempos, desde Samaipata, el 1 de febrero de 1877 Ibáñez escribió al ministro y amigo Manuel Ignacio Salvatierra ratificando su lealtad al Presidente Daza y a la integridad territorial de Bolivia. También envió una carta al Presidente, buscando un entendimiento con las autoridades nacionales.

El 2 de febrero Fabio organizó una celebración en honor a la federación de tres días. El pretendido ideólogo de la revolución Pedro Manuel Silva ${ }^{94}$, lanzó un manifiesto declarando: «La igualdad y fraternidad, legado del Evangelio triunfarán en todo el mundo, comenzando por estas partes del mundo» ${ }^{95}$. La participación en estos festejos fue obligatoria, algo que quedó agravado cuando Fabio implantó en la ciudad una serie de medidas que sembraron el terror entre los citadinos: pena de muerte y confiscación de bienes por perturbar el orden público y por «suplicar por los reos políticos»; multas en el caso de reuniones de más de tres personas o por retirarse de la ciudad sin su permiso, así como por guardar armas y por lanzar consignas contra de la federación ${ }^{96}$. Ello hizo que inclusive los igualitarios dejaran de apoyar a los revolucionarios. Ante tal descontento, Ibáñez a su regreso a Santa Cruz el 20 de febrero de 1877 ordenó el arresto del «paraguayo» y una investigación de los hechos, anulando todas las disposiciones realizadas en su ausencia, entre las que figuraba el estado de sitio. Sin embargo, Fabio fue pronto liberado. Entretanto, la expedición de la tropa de Ibáñez, compuesta de los artesanos igualitarios, cosechaba éxitos. Cerca de Samaipata la tropa de Ibáñez había derrotado a la guardia nacional local y a

${ }^{94}$ Pedro Manuel Silva fue unos de los líderes del grupo de La Montaña del 1864, también el autor de la mayoría de las proclamas del Club de Igualdad, publicadas en abril-mayo de 1876.

${ }^{95}$ La Bandera Federal, 4 de febrero, 1877.

96 Informe, 18 de mayo de 1877, ANB, MI, 1877, tomo 206, $\mathrm{n}^{\circ} 35$. 
principios de febrero ocupado Vallegrande. Después de festejar su victoria con un deslumbrante carnaval, en cuestión de pocos días Ibáñez apresuradamente dejó la ciudad, regresando a Santa Cruz, ya que había recibido la noticia de la aproximación del ejército bajo el mando del ministro de guerra, el general Carlos de Villegas. Allí, el 28 de febrero tomó la decisión de abandonar la ciudad y organizar una resistencia de guerrilla en el interior del departamento. Ibáñez estaba convencido de que las tropas de Villegas no se atreverían a perseguirlo por el vasto y despoblado territorio del Oriente. Ibáñez apostaba por estrategia militar que obligaría al gobierno central tarde o temprano, con Daza o con otro gobernante, a buscar un acuerdo con los igualitarios. Así, el 3 de marzo Ibáñez y trescientos hombres dejaron la ciudad y se dirigieron hacia la frontera brasileña.

El 9 de marzo las tropas de Villegas entraron a Santa Cruz y el 19 de marzo fue emitido un decreto de indulto a los que se entregaran voluntariamente. Sin embargo, Daza desaprobó este decreto, ordenó juzgar a los revolucionarios en consejos de guerra y confiscar sus bienes ${ }^{97}$. Aunque el ex presidente del Club de la Igualdad, Barberí, se había deslindado de sus vínculos con Ibáñez antes de la proclamación de la Federación, debió comparecer ante la justicia militar y, pese a que no le encontraron pruebas de culpabilidad, fue condenado al destierro. El periódico El Eventual llamó a esa actuación judicial «cortar el cáncer socialista que tan funestamente principia a inficionar la sociedad boliviana, comenzando por Santa Cruz» ${ }^{98}$.

A pesar de las distancias y de las condiciones del clima, Villegas decidió perseguir a «la cuadrilla igualitaria» en Chiquitos y el 13 de abril de 1877 la fuerza expedicionaria salió de Santa Cruz al este ${ }^{99}$. En este momento Villegas tuvo la noticia de que Ibáñez había tomado el pueblo de San Ignacio, desarmado a su guarnición, continuado adelante con todo el armamento cargado en mulas, $y$ acompañado con cincuenta hombres de su entera confianza ${ }^{100}$. De esas noticias, la que más alarmaba a Villegas era la relativa a las armas que podían usar de nuevo los rebeldes una vez que la División Pacificadora se hubiese retirado del departamento ${ }^{101}$. Ello no ocurrió. Ibáñez y sus más cercanos colaboradores fueron atrapados a finales de abril en un ranchito llamado San Diego, cerca de la frontera. Después de un rápido juicio llevado a cabo por un consejo de guerra verbal, el 1 de mayo de 1877, todos los prisioneros fueron fusilados.

${ }^{97}$ Kramer, 1898: 39-40.

98 El Eventual, 12 de mayo, 1877.

99 Informe al Ministro del Interior, 15 de abril de 1877, ANB, MI, 1877, tomo 206, $\mathrm{n}^{\circ} 35$.

100 Carta de Juan José Pérez al Ministro del Interior, 13 de abril de 1877, ANB, MI, 1877, tomo 206, $\mathrm{n}^{\circ} 36$.

${ }^{101}$ Carta de Juan José Pérez al Ministro del Interior, 28 de abril de 1877, ANB, MI, 1877 , tomo $206, \mathrm{n}^{\mathrm{o}} 36$. 


\section{CONCLUSiOnes}

La base del movimiento igualitario la compusieron los labradores y artesanos empobrecidos, endeudados y obligados a vender sus propiedades a los comerciantes como consecuencia de los cambios en la estructura económica del país, mientras sus líderes pertenecían a otro sector social igualmente perjudicado por ello. El conflicto social se desarrolló, así, entre la parte de la elite, integrada al nuevo sistema de libre comercio, y una conformación social heterogénea, compuesta fundamentalmente por la elite empobrecida y las clases medias y bajas. Sus ideales revolucionarios, inspirados en los socialistas europeos, dieron cuerpo al conflicto de una sociedad preindustrial en transición ${ }^{102}$.

Este trabajo ha buscado subrayar que la motivación de índole socio-económica se entretejía con el descontento de amplias capas sociales de la región ante la creciente presión del poder burocrático vinculado a los nuevos sectores locales dominantes, a los propietarios de tierra de nuevo tipo y a los nuevos ricos del mercado liberalizado. Ello quedó expresado en dos bandos en conflicto: de un lado, la unión del poder burocrático central con la elite emergente, $\mathrm{y}$, de otro, la asociación de la elite decadente y la plebe a favor de la autogestión tradicional de la democracia cabildante. El resultado fue un largo periodo de enfrentamientos protagonizados por el movimiento igualitario y materializado en una lucha entre las autoridades político-militares y el municipio. La acción del movimiento igualitario incluyó la violencia organizada de los clubes en la participación electoral y en la defensa de los poderes de la municipalidad. Lo hizo a través de un discurso legitimador que invocaba directa e indirectamente a un pasado más justo, donde los valores tradicionales de la «fraternidad patriarcal»y de la igualdad comunitaria «por ser comunes a todos los terrenos» se reinventaban a través de las fórmulas revolucionarias en boga. Las demandas locales encontraron forma y respuesta en las ideas del socialismo romántico y cristiano, de una vanguardia ideológica que predicaba asociación libre, igualdad y vida en comunidad. En Santa Cruz, una cierta homogeneidad racial permitió que los principios igualitarios conquistasen mayor popularidad entre los intelectuales, políticos y representantes de las elites locales, quienes a su vez las hicieron atractivas y comprensibles para grupos sociales y colectivos muy amplios. Se logró de esta manera una mayor identificación de los sectores populares con sus líderes ilustrados.

${ }^{102}$ Las ideas del primer socialismo con su gran diversidad de doctrinas en Europa se caracterizaba por el rechazo al capitalismo industrial, a la libre competencia y por la protección del pequeño productor, lo que selectivamente fue adoptado por los igualitarios cruceños, mientras otras ideas socialistas no encontraron ningún eco. 
El ejercicio de la violencia política como instrumento de defensa de un modo de vida igualitario formaba parte del imaginario colectivo en el Oriente boliviano con su modelo de la «democracia armada». Como tal fue percibida legítima y legal por sus componentes en la medida en que estaba destinada a restituir un orden regional vulnerado. El objetivo de la fuerza desplegada por el Club de la Igualdad, tanto en su fase «formal» como «en rebeldía», fue obtener mayor equidad social mediante una democratización del sistema político que implicase, primero, autonomía local, y, segundo, ejercicio asambleario de la soberanía popular. Para conseguirlo el partido igualitario pasó por varias estadías que fueron desde actividades electorales para la conquista del poder municipal, e inclusive el de la prefectura y presidencia, hasta la organización de un ejército que sofocase en la región las disidencias al federalismo. Durante toda su vigencia política partidaria la municipalidad actuó de brazo legal del partido, así como instancia a través de la que pretendía ejercer el poder e institucionalización de su modelo de Estado. Toda la trayectoria de los igualitarios incide en que, incluso cuando se tornaron en una montonera con estrategias de guerrilla, recurrieron al municipio para negociar con las autoridades. De hecho, pese a las formas de franca rebeldía armada que terminaron adquiriendo, siempre pretendieron llegar a un acuerdo con la presidencia, siendo la violencia un recurso para forzarlo a su favor. En este sentido, la revolución en octubre de 1876 puede interpretarse provocada por la intransigencia autoritaria de los militares al mando del departamento, y, por tanto, definirse como una revolución forzada, no deseada. La misma fue sometida para su legitimación entre el vecindario cruceño a formas de la democracia asamblearia, expresando dicho proceso una queja colectiva a la injusticia de la vida cotidiana. Sin embargo, la dinámica de violencia y abusos que desarrolló el partido igualitario en el poder en su pulso con el gobierno central provocó escisiones internas y desapego de su militancia. La proclama del federalismo tampoco lo ayudó a ganar adeptos, sobre todo por sus formas de imposición armada. Al contrario condicionó la derrota y el fin trágico de todo el experimento político y social. Es más, el federalismo en Santa Cruz se convirtió en sinónimo de comunismo, del dominio de la plebe e igualitarismo, siendo ésta la razón por la que la Revolución de los Domingos ${ }^{103}$ en enero de 1891 no fue apoyada por la elite local.

La reacción del gobierno al movimiento igualitario tuvo dos etapas. A principio, reconoció el derecho del pueblo a la resistencia ante el abuso del poder local, manifestándose ello en la aceptación indirecta de la revolución igualitaria. Luego, después de la proclama de la federación reprimió militar-

${ }^{103}$ Debe su nombre a sus líderes Domingo Ardaya y José Domingo Ávila y porque se estalló el domingo 2 de enero de 1891, bajo las consignas federalistas. 
mente el movimiento. La diferencia entre ambas respuestas residió en la conversión de los igualitarios en facciosos, en «populacho y chusma ignorante», contagiada con ideas «comunistas». Ello se produjo en un contexto nacional en el que desde la presidencia se desplegó una política tendente a desarmar a la oposición y, con ella, a la sociedad civil. La aniquilación de la montonera igualitaria y la represión militar de 1877 durante el gobierno de Daza constituyeron una expresión extrema en el proceso de desarme del ciudadano armado. El Movimiento Igualitario había recurrido a la retórica del federalismo para proteger la región de la acción destructiva del capitalismo de libre comercio responsable de asestar un golpe mortal a las estructuras tradicionales. Como no ofreció un modelo alternativo, capaz de convivir y competir con la tendencia dominante del capitalismo de libre cambio, el movimiento igualitario estaba abocado al fracaso, igual como el modo de vida que defendió, a desaparecer. La violencia desatada, primero, por la revolución y, luego, por el gobierno central, contribuyó a erradicar entre los hábitos cruceños su devoción por antiguas formas de autogestión local y de democracia cabildante. Al consiguiente decaimiento del peso político del poder municipal, cuyo auge había correspondido al periodo del movimiento igualitario, se sumó una degradación de la vida política cruceña expresada en una provincialización casi total que duraría varios decenios hasta después de la Revolución Nacional de 1952.

\section{Bibliografía}

Barberí, Carlos Melquiades, Un Deber, Santa Cruz, Imprenta el Pueblo, 1870.

Barragán, Rossana, "Las fronteras del dominio estatal: espíritu legal y territorialidad en Bolivia, 1825-1880», Umbrales, 7 (La Paz, 2000): 78-40.

Chust, Manuel y Marchena, Juan (eds.), Las armas de la nación. Independencia y ciudadanía en Hispanoamérica (1750-1850), Madrid/Frankfurt, Iberoamericana/ Vervuert, 2007.

Dalence, José María, Bosquejo estadístico de Bolivia, La Paz, UMSA, 1975.

Defensa de la revolución del Doctor Andrés Ibáñez, victimado con sus principales colaboradores, por el General Carlos de Villegas en San Diego de Chiquitos, República de Bolivia, Tacna, Imprenta de la Revista del Sur, 1877.

D'Orbigny, Alcides, Viaje a América Meridional, tomo III, Buenos Aires, Ediciones Futuro, 1945.

Dunkerley, James (ed.), Studies in the Formation of the Nation State in Latin America, London, ILAS, 2002. 
Durán Ribera, Emilio y Pinckert, Guillermo, La revolución igualitaria de Andrés Ibáñez, Santa Cruz, Universitaria, 1988.

El Doctor Andrés Ibáñez, Santa Cruz, s.n., 1872.

Elias, Norbert, La sociedad cortesana, Moscú, Yazyki slavianskoy kultury, 2002 (en ruso).

Estatuto de la compañía oriental de colonización y ganadería en las carreteras de la Empresa Nacional de Bolivia, Cochabamba, s.d., 1877.

Ferreira, Reymi, "Andrés Ibáñez, un jacobino cruceño", Vera Loreto Correa (comp.), Santa Cruz en el siglo XIX. Ponencias presentadas en el II ciclo de historia cruceña, Santa Cruz, Universitaria, 1997: 23-45.

Fouler, Will, "The Children of the Chingada", Will Fowler and Peter Lambert (eds.), Political Violence and the Constraction of National Identity in Latin America, New York, Palgraev Macmillan, 2006: 1-18.

Giddens, Anthony, The Nation-State and Violence. Volume two of A Contemporary Critique of Historical Materialism, California, University of California Press, 1985.

González-Calleja, Eduardo, La violencia en política. Perspectivas teóricas sobre el empleo deliberado de la fuerza en los conflictos del poder, Madrid, CSIC, 2002.

Guiteras Mombiola, Anna, De los llanos de Mojos a las cachuelas del Beni, 18421938, Cochabamba, Ed. Itinerarios, 2012.

Irurozqui, Marta, “A bala, piedra y palo”. La construcción de la ciudadanía política en Bolivia, 1826-1952, Sevilla, Diputación de Sevilla, 2000.

Irurozqui, Marta, “'La Guerra de Civilización'. La Participación indígena en la revolución de 1870 en Bolivia”, Revista de Indias, LXI/222 (Madrid, 2001): 407432.

Irurozqui, Marta, "EL bautismo de la violencia. Indígenas patriotas en la revolución de 1870 en Bolivia", Josefa Salmón y Guillermo Delgado (eds.), Identidad, ciudadanía y participación popular desde la Colonia al siglo XX, La Paz, Plural, 2007: 115-152.

Irurozqui, Marta, "Violencia política en América Latina, siglo XIX", Revista de Indias, LXIX/246 (Madrid, 2009): 9-16.

Irurozqui, Marta, "La justicia del pueblo. Ciudadanía armada y movilización social", Marta Irurozqui y Mirian Galante (eds.), Sangre de Ley. Violencia y justicia en la institucionalización del Estado. América Latina, siglo XIX, Madrid, Ed. PolifemoGEA, 2011a: 235-276.

Irurozqui, Marta, "Procesión revolucionaria en Semana Santa. Ciudadanía armada y represión penal en Bolivia, 1872-1875”, Miriam Galante, Marta Irurozqui y María Argeri, La razón de la fuerza y el fomento del derecho. Conflictos jurisdiccionales, 
ciudadanía y mediación estatal (Tlaxcala, Bolivia, Norpatagonia, siglo XIX), Madrid, CSIC, 2011b: 89-148.

Irurozqui, Marta, La alquimia democrática en Bolivia, 1825-1879. Ciudadanos y procedimientos representativos. Una reflexión conceptual sobre la democracia, Frankfurt, Editora Académica Española, 2011c.

Irurozqui, Marta, "Dossier Entre Lima y Buenos Aires. Acción colectiva y procesos de democratización en Argentina, Bolivia y Perú, siglo XIX”, Anuario de Estudios Americanos, 69/2 (Sevilla, 2012): 415-422.

Kramer, Pedro, General Carlos de Villegas (estudio histórico-biográfico), La Paz, Taller Tipográfico-Litográfico, 1898.

Lora, Guillermo, Historia del movimiento obrero boliviano, 1848-1900, La Paz, Amigos de los libros, 1967.

Luz sobre los sucesos de Santa Cruz, Santa Cruz, Imprenta Chávez y Hermano, 1876.

Macías, Flavia, "Entre la organización nacional, la política y las revoluciones: las fuerzas militares durante la presidencia de Domingo Faustino Sarmiento (18681874)", Marta Irurozqui y Miriam Galante (eds.), Sangre de ley. Justicia y violencia en la institucionalización del Estado en América Latina, siglo XIX, Madrid, Ediciones Polifemo, 2011: 277-310.

Macías, Flavia, Dossier "Milicias, levantamientos armados y construcción repubicana en Hispanoaméruica. Estudios y propuestas para el siglo XIX”, Boletín del Instituto de Historia Argentina y Americana Dr. Emilio Ravignani, 42 (Buenos Aires, 2015).

Méndez, Julio, Cuestión municipal en Bolivia, Lima, Tip. de La Patria, 1874.

Molina, Saucedo y Hugo, Carlos, Andrés Ibáñez, un caudillo para el siglo XXI. La comuna de Santa Cruz de la Sierra de 1976, La Paz, Plural, 2012.

Moreno, Gabriel René, Estudios históricos y literarios, La Paz, Juventud, 1983.

Nieburg, Harold, Political Violence. The Behavioral Process, New York, St. Martin Press, 1969.

Posada-Carbó, Eduardo (ed.), Wars, Parties and Nationalism. Essays on the Politics and Society of Nineteenth-Century Latin America, London, ILAS, 1995.

Roca, José Luis, Economía y Sociedad en el Oriente Boliviano (Siglo XVI-XX), Santa Cruz, Ediciones Oriente, 2001.

Roca, Ramón, A los electores, Santa Cruz, Imprenta C.R. Daza, 1871.

Romero Pittari, Salvador, "Copetudos y sin chaqueta: la revolución federal de Andrés Ibáñez”, Historia y Cultura, 5 (La Paz, 1985): 163-180.

Sábato, Hilda y Lettieri, Alberto (comps.), La vida politica en la Argentina del siglo XIX. Armas, votos y voces, Buenos Aires, FCE, 2003. 
Sanabria Fernández, Hernando, Fuentes para la historia de Andrés Ibáñez, Santa Cruz, UBGRM, 1977.

Schelchkov, Andrey, Andrés Ibáñez y La revolución de la igualdad en Santa Cruz, Santiago de Chile, USACH, 2011.

Soruco, Ximena, "De goma a la soya: el proyecto histórico de la élite cruceña", Ximena Soruco (coord.), Barones del Oriente. El poder en Santa Cruz ayer y hoy, Santa Cruz (Bolivia), Fundación Tierra, 2008: 1-101.

Tilly, Charles, From Mobilization to Revolution, Ann Arbor, University of Michigan, 1977.

Viedma, Francisco, Descripción geográfica y estadística de la provincia de Santa Cruz de la Sierra, Buenos Aires, Imprenta del Estado, 1836.

Zimmermann, Ekkart, Political Violence, Crises and Revolution. Theories and Research, New York, Routledge, 2011.

Fecha de recepción: 1 de septiembre de 2015.

Fecha de aceptación: 28 de febrero de 2016.

\section{"We Are All Equal". \\ The Equality Revolution in Santa Cruz, Bolivia. 1876-1877}

The Equality Revolution in Santa Cruz (1876-1877), also known as the equality movement, was a conflict between the pairing of the common urban class and local elites who defended a development formula that championed a modern age that balanced the social values of the traditional and patriarchal society, and other local elites who benefited from the boom of free-market capitalism. The political actions of the egalitarians was influenced by the ideology of romantic socialism in its different stages and combined legal formulas with pressure from peasant militia and civil uprisings. The disruption between the project defending a selfmanaged local way of life and local/state modernization priorities led to a state of repression rarely seen in XIX century Santa Cruz society.

Key Words: Equality Revolution; romantic socialism; federalism; civil war; Bolivia. 